\title{
Risk factors among defaulters in the urban leprosy control centre of Thaketa Township in the City of Yangon, Myanmar, 1986
}

\author{
T MYINT, M T HTOON, M WIN \& C YIN \\ Leprosy Control Programme, Department of Health, Ministry of \\ Health, Myanmar
}

\begin{abstract}
Summary A total of 884 registered cases from the city of Yangon were retrospectively analysed. The defaulter proportion among cases registered for treatment at the Thaketa Health Centre was $34 \cdot 16 \%$. It was established that patient sex and occupation are not a factor in defaulting. Paucibacillary cases and cases with no disability are more likely to default.
\end{abstract}

\section{Introduction}

Leprosy in Myanmar is one of the major health problems in both the rural and urban communities. The City of Yangon is made up of 27 townships and has a registered leprosy prevalence of 4.61 per 1000 population. ${ }^{1}$ A total of 12,107 cases were treated in 1986 by special leprosy clinics opened at the various health centres in the City of Yangon. The major problem encountered in most of these clinics is the high defaulter rate. Since the urban leprosy control programme is based on delivery of treatment services through stationary clinics where patients come in for treatment on their own, the defaulter rates are presumed to be high. This is especially a problem in Yangon City where the majority of the health workers' time is spent on opening clinics at the various health centres with very little time left for tracing defaulters. In the rural leprosy control programme, patients are being treated on a domiciliary basis where drugs are being distributed at each patient's house. Because the drugs are delivered to the patient's door-step in rural areas, the problem is not defaulting but whether the drugs are used.

Thaketa Township has a population of 206,000 and is one of the most densely populated townships in Yangon. It had a total of 884 registered leprosy cases in 1986. A leprosy clinic is open, manned by a leprosy inspector (paramedical health worker) at the township health centre. During 1986, paucibacillary cases were given dapsone monotherapy and multibacillary cases were given a monthly single dose of rifampicin $1200 \mathrm{mg}$ for 6 months along with the daily dapsone therapy.

The study was undertaken to discover the defaulter proportion and factors causing defaulters among leprosy patients attending the leprosy clinic at Thaketa Health Centre 
during 1986. This would serve as baseline data for any future comparison with MDT defaulters.

\section{Methods}

The treatment charts of 884 registered leprosy cases at the Thaketa Health Centre for 1986 were analysed retrospectively. There were 581 patients taking regular treatment and 303 cases were found to be defaulters. Out of these 303 defaulters 147 cases could not be traced at the address given at the time of treatment. From the treatment records information on age, sex, occupation, classification and the deformity state of the patient was collected.

A defaulter was defined as a leprosy case who did not collect the recommended drugs for 12 consecutive months. The remaining cases were then just categorized as cases under treatment. Out of these cases under treatment, cases getting dapsone on a monthly basis, 9 months in a year (calender year) are then defined as leprosy cases obtaining regular treatment.

Cases classified as tuberculoid and indeterminate at initial registration were grouped as paucibacillary cases and the lepromatous and borderline cases were classified as multibacillary.

\section{Findings}

Table 1 shows that the defaulter proportion is seen to be the highest in the 15- to 29-year age group, amounting to $39 \cdot 27 \%$, and the lowest is seen in the 0 - to 14-year age group, amounting to $21 \cdot 43 \%$.

The overall defaulter proportion among cases registered for treatment at the Thaketa Health Centre is $34 \cdot 16 \%(95 \%$ CI $31 \cdot 03-37 \cdot 29 \%)$.

As seen in Table 2, the defaulter proportion among males and females is similar (risk ratio $1 \cdot 05,95 \% \mathrm{CI}$ of $\mathrm{RR} 0 \cdot 95-1 \cdot 16$ ).

Table 3 shows that paucibacillary cases default more than the multibacillary cases (RR 1.62, 95\% CI 1.47-1.78).

Table 4 shows that the risk of defaulting among the different occupational categories is the same.

The risk of defaulting is the highest among cases without disability (RR $1 \cdot 52,95 \% \mathrm{CI}$ of R R 1.38-1.68), and the lowest is among those leprosy cases wth Grade II disability (Table 5).

\section{Discussion}

In 1986 out of a total of 884 registered leprosy cases at the Thaketa Health Centre $34 \cdot 16 \%$ (95\% CI $31 \cdot 03 \%-37 \cdot 29 \%)$ of them were defaulters. This was similar to that of Hertroij's ${ }^{2}$ study where $32 \cdot 4 \%$ were defaulters. In Koticha's ${ }^{3}$ study, which was conducted in Bombay, the defaulter percentage was $71 \%$. The highest defaulter proportion was in the 
Table 1. Age distribution of patients taking treatment regularly and that of the defaulters

\begin{tabular}{lcccccc}
\hline Age $(\mathrm{yr})$ & $\begin{array}{c}\text { Regular } \\
\text { treatment }\end{array}$ & $\begin{array}{c}\text { Defaulter } \\
\text { cases }\end{array}$ & Total & $\begin{array}{c}\text { Defaulter } \\
\text { proportion }\end{array}$ & $\begin{array}{c}\text { Risk } \\
\text { ratio }\end{array}$ & $95 \%$ CI of RR \\
\hline $0-14$ & 22 & 6 & 28 & $0 \cdot 02143$ & $1 \cdot 0$ & \\
$15-29$ & 183 & 119 & 302 & $0 \cdot 3927$ & $1 \cdot 83$ & $1 \cdot 48-2 \cdot 27$ \\
$30-44$ & 170 & 80 & 250 & $0 \cdot 32$ & $1 \cdot 49$ & $1 \cdot 21-1 \cdot 84$ \\
$45-59$ & 143 & 64 & 207 & $0 \cdot 3092$ & $1 \cdot 44$ & $1 \cdot 16-1 \cdot 78$ \\
60 & 63 & 34 & 97 & $0 \cdot 3505$ & $1 \cdot 64$ & $1 \cdot 29-2 \cdot 09$ \\
Total & 581 & 303 & 884 & $0 \cdot 3416$ & & $0 \cdot 3103-0 \cdot 3729$ \\
\hline
\end{tabular}

Table 2. Sex distribution of patients taking regular treatment and that of the defaulters

\begin{tabular}{lcccccc}
\hline Sex & $\begin{array}{c}\text { Regular } \\
\text { treatment }\end{array}$ & $\begin{array}{c}\text { Defaulter } \\
\text { cases }\end{array}$ & Total & $\begin{array}{c}\text { Defaulter } \\
\text { proportion }\end{array}$ & $\begin{array}{c}\text { Risk } \\
\text { ratio }\end{array}$ & $95 \%$ CI of RR \\
\hline Male & 372 & 189 & 561 & $0 \cdot 3368$ & $1 \cdot 0$ & \\
Female & 209 & 114 & 323 & $0 \cdot 3529$ & $1 \cdot 05$ & $0.95-1 \cdot 16$ \\
\hline
\end{tabular}

Table 3. Defaulter proportion among paucibacillary and multibacillary cases

\begin{tabular}{lcccccc}
\hline $\begin{array}{l}\text { Type } \\
\text { leprosy }\end{array}$ & $\begin{array}{c}\text { Regular } \\
\text { treatment }\end{array}$ & $\begin{array}{c}\text { Defaulter } \\
\text { cases }\end{array}$ & Total & $\begin{array}{c}\text { Defaulter } \\
\text { proportion }\end{array}$ & $\begin{array}{c}\text { Risk } \\
\text { ratio }\end{array}$ & $95 \%$ CI of RR \\
\hline $\begin{array}{l}\text { Paucibacillary } \\
\text { Multibacillary }\end{array}$ & 323 & 218 & 541 & 0.403 & 1.62 & $1 \cdot 47-1 \cdot 78$ \\
& 258 & 85 & 343 & 0.2478 & 1.0 & \\
\hline
\end{tabular}

Table 4. Occupation of patients taking regular treatment and that of the defaulters

\begin{tabular}{lcccccc}
\hline & $\begin{array}{c}\text { Regular } \\
\text { treatment }\end{array}$ & $\begin{array}{c}\text { Defaulter } \\
\text { Cases }\end{array}$ & Total & $\begin{array}{c}\text { Defaulter } \\
\text { proportion }\end{array}$ & $\begin{array}{c}\text { Risk } \\
\text { ratio }\end{array}$ & $95 \%$ CI of RR \\
\hline Unemployed & 42 & 19 & 61 & $0 \cdot 3115$ & $1 \cdot 0$ & \\
Students & 119 & 64 & 183 & $0 \cdot 3497$ & $1 \cdot 12$ & $0 \cdot 92-1 \cdot 24$ \\
Government workers & 99 & 52 & 151 & $0 \cdot 3444$ & $1 \cdot 11$ & $0 \cdot 90-1 \cdot 36$ \\
Private sector workers & 159 & 78 & 237 & $0 \cdot 3291$ & $1 \cdot 06$ & $0 \cdot 88-1 \cdot 28$ \\
Housewife & 154 & 82 & 236 & $0 \cdot 3475$ & $1 \cdot 12$ & $0 \cdot 92-1 \cdot 36$ \\
Others (monks and pensioners) & 8 & 8 & 16 & $0 \cdot 5$ & $1 \cdot 61$ & $0 \cdot 95-2 \cdot 70$ \\
\hline
\end{tabular}

Table 5. Disability occurring among patients taking regular treatment and that of defaulters

\begin{tabular}{lcccccc}
\hline $\begin{array}{l}\text { Disability } \\
\text { grading } \\
\text { (grades) }\end{array}$ & $\begin{array}{c}\text { Regular } \\
\text { treatment }\end{array}$ & $\begin{array}{c}\text { Defaulter } \\
\text { cases }\end{array}$ & Total & $\begin{array}{c}\text { Defaulter } \\
\text { proportion }\end{array}$ & $\begin{array}{c}\text { Risk } \\
\text { ratio }\end{array}$ & $95 \%$ CI of RR \\
\hline O & 376 & 228 & 604 & $0 \cdot 3775$ & $1 \cdot 52$ & $1 \cdot 38-1 \cdot 68$ \\
I & 51 & 24 & 75 & $0 \cdot 3210$ & $1 \cdot 29$ & $1 \cdot 08-1 \cdot 54$ \\
II & 154 & 51 & 205 & $0 \cdot 2488$ & 1.0 & \\
\hline
\end{tabular}


15- to 29 -year age group $(39 \cdot 27 \%)$, which is also the peak age of onset of leprosy in Myanmar.

As also demonstrated in Hertroij' ${ }^{2}$ and Koticha's ${ }^{3}$ studies, sex does not seems to be a factor in defaulting. The risk of defaulting is seen to be much higher among paucibacillary cases (RR 1·62,95\% CI 1·47-1·78). Because of their infiltrated lesions multibacillary cases may be more conscious of their appearances and this might motivate them to take treatment more regularly. As for the paucibacillary cases, because the disease apparently looks so benign, they may even doubt the diagnosis and therefore may be less willing to take treatment regularly. In Hertroij's ${ }^{2}$ study it was also observed that tuberculoid cases defaulted more, but in Koticha's ${ }^{3}$ study BB and BL cases were found to be more regular than LL or BT cases. In Koticha and Nair's ${ }^{4}$ study smear-positive cases, particularly borderline types, were seen to be more regular.

The occupation of patients is not a factor for defaulting, but it is surprising to note that out of 151 cases who were government employees, $34.44 \%$ of them were defaulters, and out of 183 students registered for treatment $34.97 \%$ of them were defaulters'. These 2 categories of people should be highly motivated to obtain treatment, and finding a similar proportion of defaulters among them as compared to other occupations denotes that proper health education to each individual patient is much in need.

Table 5 shows that the risk of defaulting is seen to be the highest among leprosy cases with no disabilities (RR 1·52, 95\% CI 1·38-1·68). Patients with grade II disability are seen to be less likely to be defaulters. Cases without deformity may be less motivated to obtain treatment, whereas for those leprosy patients with disabilities, they may be coming for treatment as a result of these disabilities. This was also found in both Hertroij's ${ }^{2}$ and Koticha's ${ }^{3}$ studies, where deformed cases are more regular in their treatment. This finding ref utes the previous thinking that deformed cases, due to their difficulty in travelling, are more prone to default.

\section{Acknowledgments}

We are grateful to the staff of the Thaketa Township Health Centre and also to the patients, who have been very co-operative.

\section{References}

1 Annual Report of the Leprosy Control Programme. Department of Health, Ministry of Health, Myanmar. 1985.

2 Hertroijs AR. A study of some factors affecting the attendance of patients in a leprosy control scheme. Int $J$ Lepr, 1974; 42: 419-427.

3 Koticha KK. et al. Problems of urban leprosy control with special ref erences to case holding. Int J Lepr, 1984; 52: $482-484$.

4 Koticha KK, Nair PRR. Defaulters in treatment of leprosy, A retrospective study of 42,000 cases. Int J Lepr, 1979; 47: 50-55. 
Facteurs du risque d'abandon du traitement au centre urbain de contröle de la lèpre de la commune de Thaketa, dans la cité de Yanton, Myanmar, 1986

\author{
T Mrint, M T Htoon, M Win et C Yin
}

Résumé Nous avons analysé rétrospectivement un total de 884 cas recensés provenant de la ville de Yangon. La proportion des abandons parmi les cas inscrits pour un traitement au Centre sanitaire Thaketa était de $34,16 \%$. Nous avons établi que le sexe et l'occupation des patients ne sont pas un des facteurs de l'abandon. Les cas paucibacillaires et les cas sans invalidité sont plus susceptibles d'abandonner le traitement.

\title{
Los Factores de Riesgo en los Incomparecentes en el Centro Urbano de Control de la Lepra en el término municipal de Thaketa, en la ciudad de Yangon, Myanmar, 1986
}

T Myint, M T Htoon, M Win y C Yin

Resumen Se analizaron retrospectivamente un total de 884 casos registrados de la ciudad de Yangon. La proporción de incomparecentes entre los casos registrados para tratamiento en el Thaketa Health Centre fue $34,16 \%$. Se estableció que ni el sexo ni el oficio erán causas de incomparecencia. Los casos con mayor probabilidad de incomparecencia eran los paucibacilares y los sin incapacidad. 